\title{
Current Applications of PRP and SVF Fractions in Stem Cell Therapy
}

\author{
Fasasi Olaleke Bashir \\ Panama College of Cell Science, Azuero Business centre, Suite 758 Avenida Perez Chitre 00395, Panama, Republic de panama
}

\begin{abstract}
The ease of harvesting stromal vascular fraction (SVF) and the preponderance of progenitor cell populations with proven in vitro expansion and multilineage differentiation potential make it a sort after for regenerative therapy. Also, a complex of growth factors and other cytokines recoverable from platelet rich plasma (PRP) are crucial to a complete regenerative protocol in the treatment of organ and tissue defects. Nevertheless, we do know as tissues are created disparately and so are the bio-molecular requirements of damaged multifarious tissues. This article brings to bare recent facts on SVF and PRP physiological role in tissue regeneration modalities and as a guide for future exploit in the translational medicine. An internet database research of published articles from 2015 till date was conducted with average age of study group being below 50years but not morbidly obese as it concerns advances in applications of platelet rich plasma and stromal vascular fraction. GID-SVF1 separation kit offers the fastest SVF Isolation time of $\sim 90$ minutes compared to other techniques with no significant difference in SVF yields and preserved viability of isolated TNC highest at $(81.47 \% \pm 1.44)$ especially in young adults. This systematic best evidence review shows that autologous growth factor in PRP stimulate neoangiogenesis when injected fortnightly to initiate wound closure and re-epithelialization in chronic ulcers and burns especially where previous treatments had failed. Concomitant use of PRP and SVF was also found to improve skin regeneration, facial rejuvenation, facial scars, soft tissue defects and breast reconstruction surgeries. Anatomic origin and age of fat cells is crucial to their adipogenic, differentiation and commitment abilities with male superficial fat differentiating faster. However, an assessment of 'peroxisome proliferator-activated receptor- $\gamma$ ' $(P P A R-\gamma)$ and PPAR- -2 indicator will be a guide.
\end{abstract}

Keywords: Stromal Vascular fraction, Platelet rich plasma, peroxisome proliferator-activated receptor- $\gamma^{\prime}$, neoangiogenesis, reepithelialization

\section{Introduction}

Platelet-rich plasma (PRP) is otherwise referred as autologous conditioned plasma (a concentrate of plateletrich plasma protein and inflammatory cells) derived from whole blood through dual segmented centrifugation to take out red blood cells $(1,2)$ While Stroma vascular fraction (SVF) is an extract of adipose tissue containing an heterogeneous collection of cells such as mesenchymal progenitor/stem cells, mast cells, preadipocytes, endothelial cells, pericytes, $\mathrm{T}$ cells, smooth muscle cells and M2 macrophages (3 and 4). The platelets are small, anuclear, discoid cells with primary function of hemostasis and coagulation. The PRP on the other hand has about 5times platelets than normal value. It is a complex of growth factors and other cytokines like the platelet-derived growth factor, transforming growth factor beta (TGF- $\beta$ ), fibroblast growth factor, insulin-like growth factor $1 \& 2$, vascular endothelial growth factor, epidermal growth factor, Interleukin 8, keratinocyte growth factor and connective tissue growth factor (5). Conventionally, SVF is extracted from lipoaspirate in a stepwise protocol to breed Adipose-derived stem/stromal cells (ASCs). However, the quest for high quality, purified ASCs lead to development of semiautomated devices which been tested to augment efficiency and a reproducible end results. Currently the GID SVF-1 ${ }^{\text {TM }}$ has been demonstrated to recover more cells with preserved viability and cell phenotype using flow cytometry analysis (6).

The rationale of this review is to underline the most recent advances in therapeutic relevance of SVF and PRP in everyday medicine.

\section{Materials and Method}

A computer based internet research of published articles was performed (case report published from frontiers in medicine, leading open access and highest cited publisher) to identify all studies on the subjects. Also, publications of leading experts, meta-analysis report of finding national bodies in the industry like SIMTI Servizi Srl database of blood transfusion journal was explore for review materials between 2015 and 2019 as it relates to recent advances in applications of platelet rich plasma and stromal vascular fraction in the treatment of diseases. One of the selection criteria was the age of study group in published being below 50years and paper did not capture review of morbidly obese candidates. To exploit sensitivity and specificity, a list of carefully chosen text were used like in the search recent application of 'Platelet-rich plasma', 'neurological disorder', 'orthopaedic', efficacy of "stromal vascular fraction", 'treatment', “joint inflammation', treatment, "'osteochondral', '"knee defect', 'adipose derived stromal cells', regenerative medicine.

\section{Result}

This paper demonstrates the typical procedure for the collection of SVF from fatty tissue lipoaspirates and plateletrich plasma from peripheral blood.

Tissue Collection Technique: The choice of adipose tissue harvest methods bothers on certain clinical parameters and as such a couple of options have been explored as seen in various papers that fulfilled (several criteria: Table 1) user friendliness in a surgical unit and Good Manufacturing Practice (GMP) facilities and to present viable and genetically stable ASC cells with a yield not significantly

Volume 9 Issue 3, March 2020 


\section{International Journal of Science and Research (IJSR) \\ ISSN: 2319-7064}

ResearchGate Impact Factor (2018): 0.28 | SJIF (2019): 7.583

different from reference method but meets ISCT criteria. However, modern practices all agreed adipose tissue (Figure 1c) should be washed on the average of 3 times in $20 \mathrm{~mL}$ syringes to remove lipoaspirate fluids, weighed and then digested in $\operatorname{LR}(1: 1, \mathrm{v} / \mathrm{v}$, fat/LR) containing collagenase $\mathrm{NB} 6$ at a final concentration of $0.1 \mathrm{U} / \mathrm{ml}$ at $37^{\circ} \mathrm{C}$ for $45 \mathrm{~min}$ and under constant shaking (6).

- Conventional method involving liposuction at $-330 \mathrm{mmHg}$ into canister and no further manipulation in operation theatre prior to processing laboratory.

- Puregraft collection method where in addition to the immediate above fat is directed to an intermediate canister before a 60cc syringe would be used to inject tissue into Puregraft filtration bag to drains the tumescent fluid, free lipid, blood cells and excess fluid from the graft

- Also there is Stem.Pras where a vacuum pump is connected into the device with the suction tube arising from the device to the harvesting cannula. In essence, fat goes in directly to the Stem,pras container without further meddling.

- The last option in current use for fat tissue collection is the GID-SVF1 (figure 1c) which simply incorporates an additional filtration system that engenders immediate separation of fluid and fat collected. This device make use of manufacturer packed GIDzyme-2 kit (a mix of Collagenase) to dissociate adipose tissue.

Following the literature search undertaken as described above, the following criteria were found to benchmark the efficiency of any chosen technique in deploring PRP and SVF for therapy in recent papers viz:

- Tissue processing time

- The quantity of fat harvested

- The total viable nucleated cells

- The viability of harvested cells

- The remaining erythrocytes before the red blood cell lyses

- Culture characteristics (phenotype, proliferation potential, genetic stability, multilineage differentiation and overall practicability of device.

On the whole, the factors related above are not unconnected to donor age, colour (white or brown) and origin (subcutaneous or visceral) of adipose tissue, type of surgical procedure, culture conditions, exposure to plastic, plating density, and medium formulations as far as proliferation rate as well as the differentiation potential of these cells is concerned (4). One thing was clear from our update findings and that is "GID-SVF1 offers the fastest SVF Isolation time of 90 minutes" compared to any other techniques or conventional method that gulp 150minutes, though there was no significant difference in SVF yields. The viability of isolated TNC was found to be highest at $(81.47 \% \pm 1.44)$ in the GID-SVF1 technique. The growth rate of ASC was found to be highest patient of ages 25-30 years (6).

\section{Typical Separation Protocol}

- End digestion using Dulbecco's Modified Eagle's Medium (DMEM with GlutaMAX_, Gibco_, Carlsbad, USA) with $10 \% 10 \%$ fetal calf serum

- Centrifuge at $300 \mathrm{~g} / \mathrm{min}$ and discard floating supernatant (adipocytes)

- Suspend pellet (SVF) in media and spin for $5 \mathrm{~min}$ at $300 \mathrm{~g} /$ minute

- Filter pellet through $70 \mu \mathrm{m}$ sieve

- Perform Red blood cells (RBC) count using a Pentra $60 \mathrm{C}+$ (Horiba Medical, Kyoto, Japan)

- Incubate Cell pellet in erythrocyte lysis buffer (HybriMax_, Sigma-Aldrich, Saint-Quentin-Fallavier, France) for $20 \mathrm{~min}$ at $37 \circ \mathrm{C}$. Centrifuge and take count of total nucleated cells (TNC) using Trypan blue exclusion method.

\section{GID-SVF1 Protocol Enhancement}

- At third wash, weigh the device to calculate the total adipose tissue mass, whereas GIDSVF1 tare was $254 \mathrm{~g}$

- During digestion the LR was incorporated with GIDzyme-2 by manufacturers stipulation at the ratio of 1 vial for 100-175 $\mathrm{g}$ of fat

- Incubated at $37^{\circ} \mathrm{c}$ on shaking rocker

- Terminate Collagenase reaction with device provided fetal calf serum

- Wash the entire device at $800 \mathrm{~g} \cdot \mathrm{min}^{-1}$ for 10 minutes and removed the oil layer

- Resuspend pellet in LR and wash few more times through spinning

- At second wash, decant top layer and remove pellet into $50 \mathrm{ml}$ conical tube for red cell counting and its immediate lyses.

Having established the ideal protocol to harvest and process with reference to findings on Google scholar, frontiers in medicine, Hindawi Publishing Corporation, national institute of health, Rome publications in recent years, here are the parameters with which a chosen technique of separation and processing can be assessed for clinical and therapeutic relevance viz:

- Processing time

- Stroma Vascular fraction Cell yield with regards to ASC characterization, Proliferative and chondrogenic capabilities and genetic stability. 


\section{International Journal of Science and Research (IJSR) \\ ISSN: 2319-7064}

ResearchGate Impact Factor (2018): 0.28 | SJIF (2019): 7.583

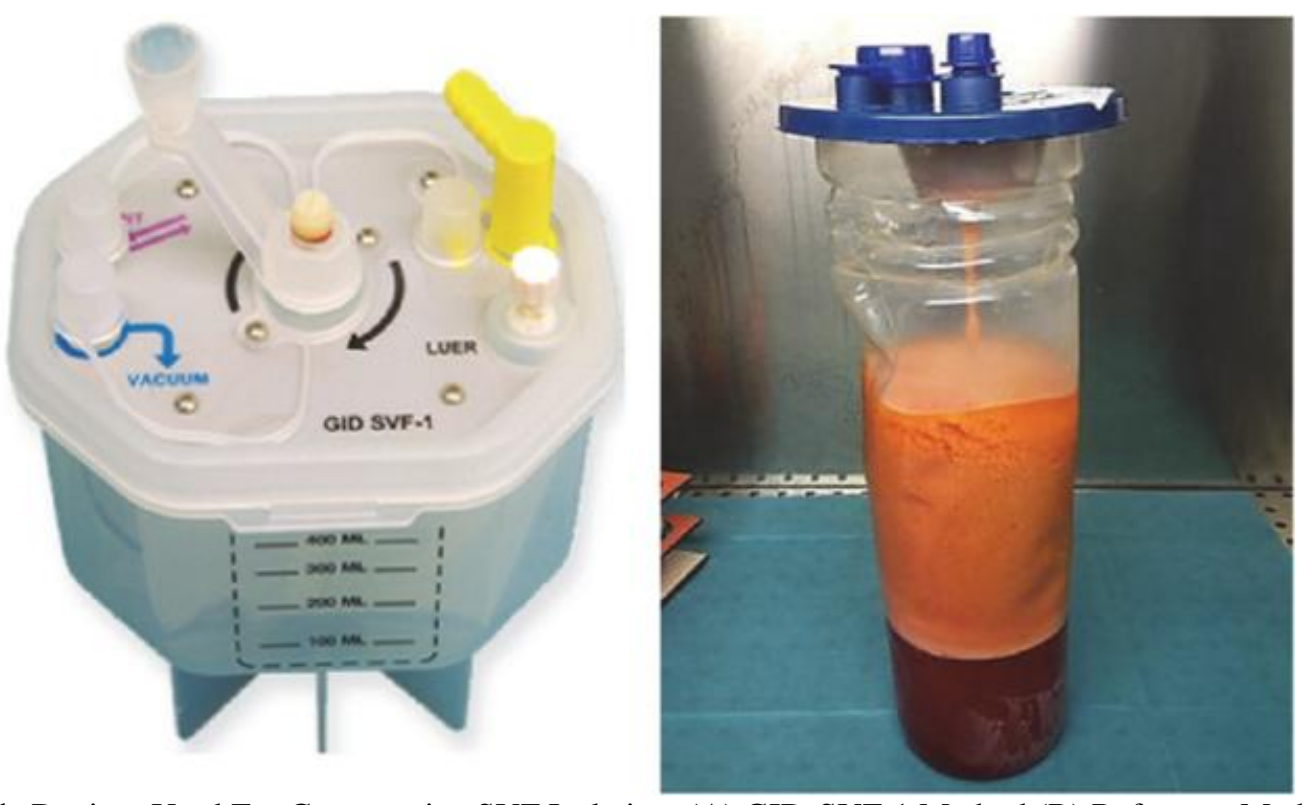

Figure 1: Devices Used For Comparative SVF Isolation. (A) GID-SVF-1 Method (B) Reference Method (6)

Table 1: List of Devices for SVF Isolation. (6)

\begin{tabular}{|c|c|c|c|c|c|c|c|c|c|}
\hline Device & Company & $\begin{array}{l}\text { Open/ } \\
\text { semi- } \\
\text { closed }\end{array}$ & $\begin{array}{c}\text { Automated/ } \\
\text { semi- } \\
\text { automated }\end{array}$ & $\left|\begin{array}{c}\text { Maximum } \\
\text { fat } \\
\text { quantity }\end{array}\right|$ & $\begin{array}{l}\text { Method for } \\
\text { fluid }\end{array}$ & $\begin{array}{c}\text { Collagenase } \\
\text { provided }\end{array}$ & $\begin{array}{c}\text { Disposable } \\
\text { cost }(\$)\end{array}$ & $\begin{array}{c}\text { Fat } \\
\text { Treatment } \\
\text { duration } \\
\text { (minutes) } \\
\end{array}$ & Publication \\
\hline \multirow[t]{2}{*}{ Celution } & Cytori Therapeutics, Inc. & closed & manual & $(\mathrm{g})$ & separation & (yes/no) & & & \\
\hline & & $\begin{array}{l}\text { Semi- } \\
\text { closed }\end{array}$ & Automated & 300 & Decantation & Yes & 1950 & 90 & [8] \\
\hline \multirow[t]{2}{*}{ 800/CRS } & http://www.cytori.com & & & & & (Celase) & & & \\
\hline & PNC International Co., Ltd. & & & & & & & & \\
\hline $\begin{array}{c}\text { Cha- } \\
\text { Station }\end{array}$ & $\begin{array}{c}\text { http://inphronics.com.sg/equipment/cha- } \\
\text { station }\end{array}$ & $\begin{array}{l}\text { Semi- } \\
\text { closed }\end{array}$ & $\begin{array}{c}\text { Semi- } \\
\text { automated }\end{array}$ & 200 & Not provided & No & 710 & 90 & [8] \\
\hline $\begin{array}{c}\text { GID } \\
\text { SVF-1 }\end{array}$ & GID Group, Inc. & Closed & Manual & 300 & Filtration & Yes & 500 & 90 & {$[24,28]$} \\
\hline $\begin{array}{l}\text { Lipokit } \\
\text { with }\end{array}$ & http://www.thegidgroup.com/ & & & & & $\begin{array}{c}\text { (GIDzyme- } \\
2)\end{array}$ & & & \\
\hline \multirow[t]{3}{*}{ Maxstem } & Medi-Khan & $\begin{array}{l}\text { Semi- } \\
\text { closed }\end{array}$ & Manual & 100 & Centrifugation & No & 530 & 110 & [8] \\
\hline & http://www.medikanint.com/ & & & & & & & & \\
\hline & PNC International Co., Ltd. & & & & & & & & \\
\hline \multirow[t]{2}{*}{$\begin{array}{c}\text { Multi } \\
\text { Station } \\
\end{array}$} & PNC North America & open & Manual & $100-150$ & Centrifugation & No & 460 & 110 & [8] \\
\hline & http://pncint.business1.com/ & & & & & & & & \\
\hline \begin{tabular}{|c|}
$\begin{array}{c}\text { Puregraft } \\
250\end{array}$ \\
\end{tabular} & Eurosilicone & $\begin{array}{l}\begin{array}{l}\text { Semi- } \\
\text { closed }\end{array} \\
\end{array}$ & Manual & 250 & Filtration & No & 250 & $100^{\dagger}$ & {$[23]$} \\
\hline \multirow[t]{2}{*}{ Sepax } & Biosafe Group SA & $\begin{array}{l}\text { Semi- } \\
\text { closed }\end{array}$ & $\begin{array}{c}\text { Semi- } \\
\text { automated }\end{array}$ & 300 & Not provided & No & 420 & $90-120$ & [29] \\
\hline & https://www.biosafe.ch & & & & & & & & \\
\hline $\begin{array}{c}\text { Stem.pras } \\
\text { with } \\
\text { Duografter } \\
\text { II }\end{array}$ & Proteal & closed & Manual & $200^{\dagger}$ & Decantation & No & Unknown & $110^{\dagger}$ & None \\
\hline $\begin{array}{c}\text { Tissue } \\
\text { Genesis }\end{array}$ & Tissue Genesis, Inc. & $\begin{array}{l}\text { Semi- } \\
\text { closed }\end{array}$ & $\begin{array}{c}\text { Semi- } \\
\text { automated }\end{array}$ & 60 & Not provided & Yes & Unknown & 80 & [9] \\
\hline Icellator & http://www.tissuegenesis.com/icellator & & & & & Adipase & & & \\
\hline
\end{tabular}

Volume 9 Issue 3, March 2020 www.ijsr.net

Licensed Under Creative Commons Attribution CC BY 


\section{International Journal of Science and Research (IJSR)}

ISSN: 2319-7064

ResearchGate Impact Factor (2018): 0.28 | SJIF (2019): 7.583

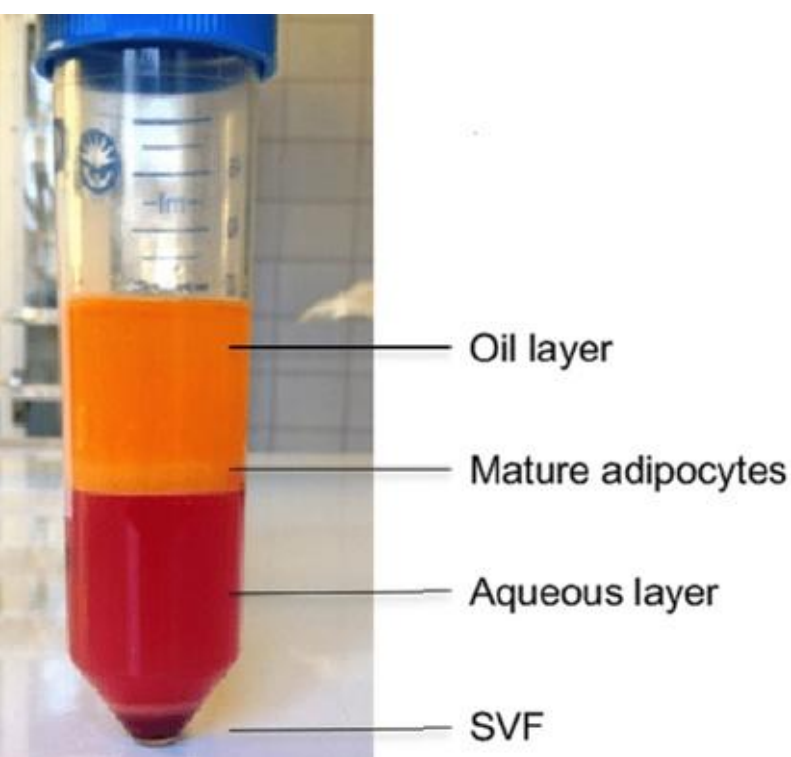

Figure 1(c): Fractions of separated adipose tissue

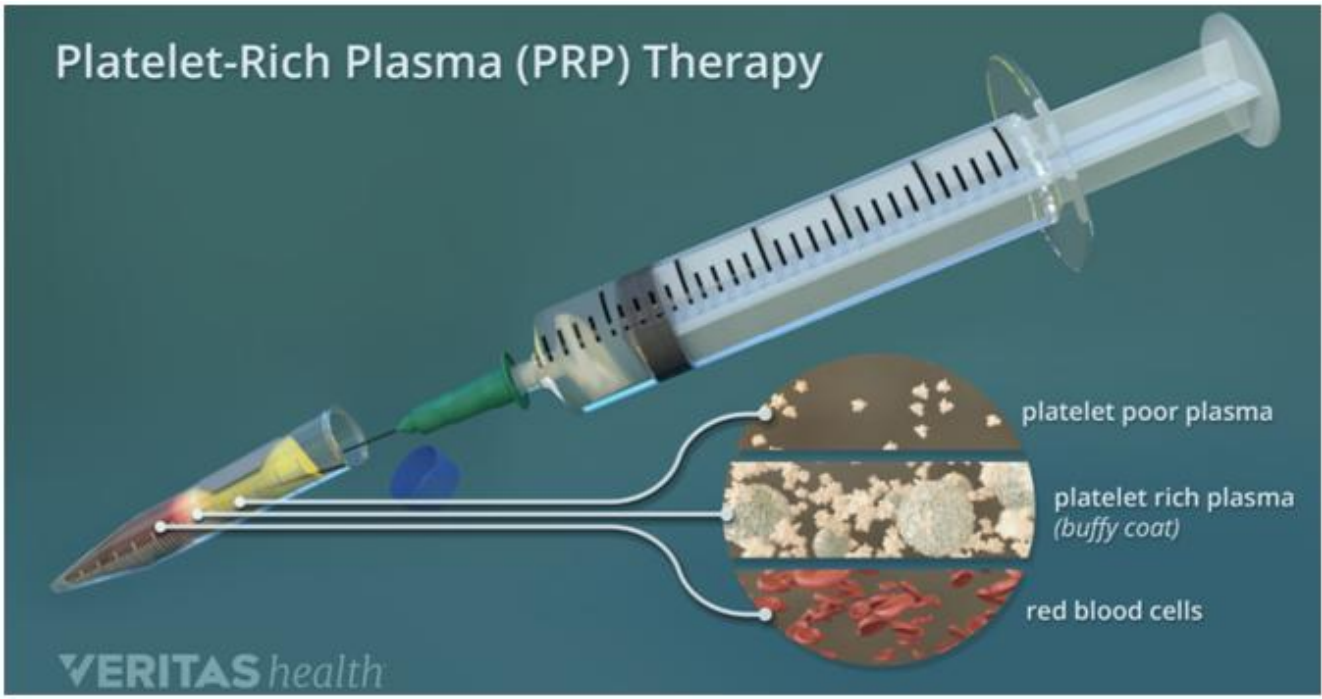

Figure 1(d): Centrifuge Separated peripheral blood

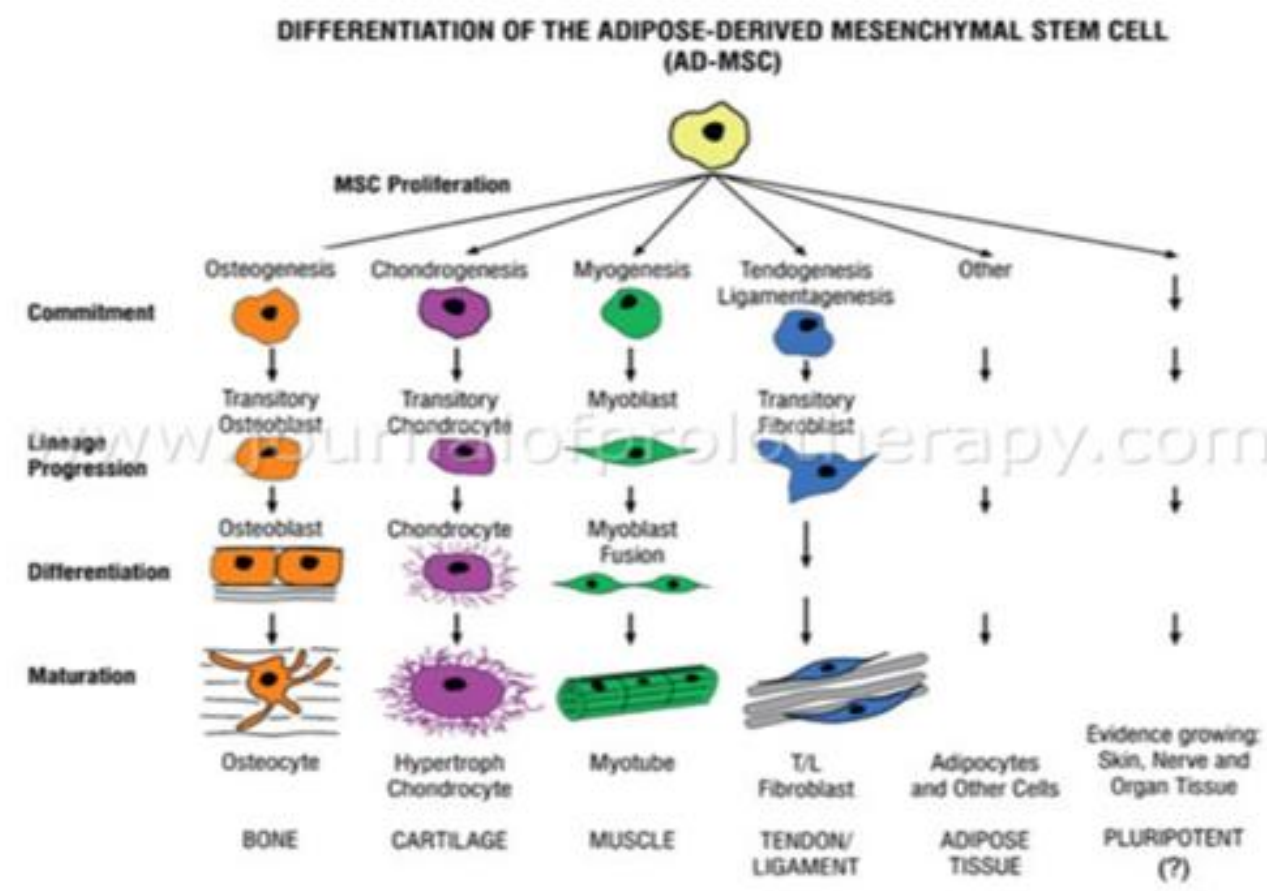

Figure 1: Differentiation potential of Adipose Derived Stromal Vascular Fraction

Volume 9 Issue 3, March 2020

www.ijsr.net

Licensed Under Creative Commons Attribution CC BY 


\section{International Journal of Science and Research (IJSR) \\ ISSN: 2319-7064}

ResearchGate Impact Factor (2018): 0.28 | SJIF (2019): 7.583

\section{PRP Harvest Protocol}

Recent advances in stem cell therapy has caused more and more commercial vendor to grace the scene of commercially prepared autologous PRP available. However, the entire near fifty (50) commercial systems all deployed a two step application of centrifugal force to separate blood constituents at varying gradients, speed and time on account individual molecular weight of each of the cellular component. It must however be noted that a couple of factors contributes to final thrombocytes concentration like the age, health status, commercial kit used and circulation. The entire processing is in four phases blood collection, centrifugation for platelet concentration, induction of gelation (if the PRP is to be used in gel form), and activation (7).

- At first spin, the densest red blood cell settles for the container bottom flowed by buffy coat and topmost the plasma.

- Separate buffy coat and plasma in new tube; pull all other set up from patient own blood sample and re-spin (second centrifugation) for improved harvest.
- Perform platelet count and document

Note Before: Early scholars' recent reports differ on the thrombocytes concentration for PRP therapy to be helpful but a safety band of $800-1200 \times 10^{9}$ platelets/L proven to be minimal clinical therapeutic threshold (8)

Whatever the technique and medical device, expanded cells show the same phenotype as determined by way flow cytometry. Growth results of cultured cells from the two methods did not show any statistical differences in multilineage differentiation. To establish whether the cells obtained from the two methods were able to differentiate toward the three recommended lineages $(9,10)$, exposure of ASC at passage 1 to adipogenic, osteogenic and chondrogenic medium was used to prove claims.

Table 2: Below relate the extent of work and update in protocols for processing PRP (5)

Table 2: Platelet Rich Plasma Collection Systems

\begin{tabular}{|c|c|c|c|c|c|c|}
\hline Study \& Procedures & $\begin{array}{c}\text { Processed } \\
\text { Bld }(\mathrm{ml})\end{array}$ & Anti-Coagulant & \begin{tabular}{|c} 
Centrifugation $1^{\text {st }}$ \\
Step (Rcf - G- \\
Force $)$
\end{tabular} & $\begin{array}{c}\text { Centrifugation } 2^{\text {nd }} \\
\text { Step } \\
\text { (Rcf-G-Force) }\end{array}$ & Activator & Platelet Count Rise \\
\hline $\begin{array}{l}\text { Mazzucco et al. } \\
\text { FIBRINET }\end{array}$ & 7 & $\begin{array}{c}\text { ACD1 } \\
\text { separator gel } \\
\end{array}$ & $1,100 \mathrm{~g}$ x 10 minutes & $1,500 \mathrm{~g} \times 15 \mathrm{~min}$ & $\begin{array}{l}\mathrm{Ca}^{2+}, \text { High speed } \\
\text { centrifugation }\end{array}$ & $1358 \pm 419 \times 10^{3}$ \\
\hline $\begin{array}{l}\text { Mazzucco et al. } \\
\text { PLATELTEX }\end{array}$ & 6 & Sodium citrate & $180 \mathrm{~g}$ x 10 minutes & $1,000 \mathrm{~g} \mathrm{x} 10 \mathrm{~min}$ & $\mathrm{Ca}^{2+}$, batroxobin & $1160 \pm 164 \times 10^{3}$ \\
\hline $\begin{array}{l}\text { Mazzucco et al. } \\
\text { EGEN }\end{array}$ & 8 & $\begin{array}{c}\text { ACD 1 } \\
\text { separator Gel }\end{array}$ & $1,500 \mathrm{~g} \times 10$ minutes & & $\begin{array}{l}\text { Autologous } \\
\text { thrombin }\end{array}$ & $430 \pm 109 \times 10^{3}$ \\
\hline \begin{tabular}{|c|} 
Gentile et al. \\
Cascade-Selphyl- \\
Esforax \\
\end{tabular} & $9-18$ & $\begin{array}{c}\text { ACD } 1 \\
\text { separator Gel }\end{array}$ & $1,100 \mathrm{~g}$ x 10 minutes & $1,500 \mathrm{~g}$ x15 minutes & $\begin{array}{l}\mathrm{Ca}^{2+}, \text { High speed } \\
\text { centrifugation }\end{array}$ & $8.8 \times 10^{4}, 2$ times \\
\hline Gentile et al. & 60 & $\mathrm{ACD}$ & $260 \mathrm{~g} \times 10$ minutes & $1,200 \mathrm{~g} \mathrm{x} 10$ minutes & - & 4 times \\
\hline C-PUNT & & & & & & \begin{tabular}{|c|} 
Plasma 553.1 $\pm 43.79 \times 10^{6}$ \\
PRP 925.9 $\pm 52.03 \times 10^{6}$
\end{tabular} \\
\hline Amable et al. & 4.5 & Sodium citrate & $300 \mathrm{~g}$ x 5 minutes & $700 \mathrm{~g} \times 17$ minutes & - & $1.4310^{6}-1.9 \times 10^{6}$ \\
\hline & & & & & \multirow[b]{2}{*}{$\mathrm{Ca}^{11}$} & 5.4-fold - 7.3-fold \\
\hline Anitua et al. & 4.5 & $\begin{array}{c}\text { Sodium citrate } \\
1\end{array}$ & $580 \mathrm{~g}$ x 8 minutes & - & & 2.67 times \\
\hline $\begin{array}{l}\text { PRGF Endoret } \\
\text { (BTI) }\end{array}$ & & buffy coat & & & & \multirow[t]{2}{*}{$1.222 \pm 166310^{3}$} \\
\hline Amanda et al. & 3.5 & & $100 \mathrm{~g} \times 10$ minutes & $400 \mathrm{~g}$ x 10 minutes & - & \\
\hline & & & & & & 5-fold \\
\hline Kahn et al. & 478 & - & 3731g 34 minutes & - & - & $8.3310^{10}$ \\
\hline Slichter and Harker & $250-450$ & - & $1000 \mathrm{~g} \times 9$ minutes & $3000 \mathrm{~g}$ x 20 minutes & - & $80 \%$ recovery \\
\hline Landesberg et al. & 5 & - & $200 \mathrm{~g}$ x 10 minutes & $200 \mathrm{~g}$ x 10 minutes & - & $5.57-9.35 \times 10^{8}$ \\
\hline \multirow[t]{2}{*}{ Jo et al. } & 9 & - & $900 \mathrm{~g}$ x 5 minutes & $1,500 \mathrm{~g}$ x 15 minutes & - & $633.2 \pm 91.6 \times 10^{3}$ \\
\hline & & & & & & 4.2 times \\
\hline Bausset et al. & 8.5 & - & $250 \mathrm{~g} \times 15$ minutes & $250 \mathrm{~g} \times 15$ minutes & - & 3.96 times \\
\hline Mantalvo et al. & 8.5 & - & $160 \mathrm{~g}$ x 10 minutes & $400 \mathrm{~g} \mathrm{x} 10$ minutes & - & $630.2 \times 10^{3}$ \\
\hline Araki et al. & 7.5 & - & $270 \mathrm{~g}$ x 10 minutes & $2,300 \mathrm{~g}$ x 10 minutes & - & $189.6 \times 10^{4}$ \\
\hline Kececi et al. & 9 & - & 250g 310 minutes & $750 \mathrm{~g} 310$ minutes & - & $679.9310^{3}$ \\
\hline
\end{tabular}

\section{Discussion}

The autologous growth factor derived from platelet naturally has the innate potential to stimulate neoangiogenesis, cell proliferation and differentiate which are the bedrock of wound healing process hence their extended application in scars and burn tissues regeneration (11). One of the major documented interventions of PRP in translational medicine is its applications in plastic surgery especially in dressing, management and healing of chronic wounds involving venous lower extremity ulcers, pressure ulcers and diabetic foot ulcers (DFUs) and burns (12 and 13). Injection of PRP on a fortnight basis especially where previous treatments had failed was found to initiate wound closure and re-

\section{Volume 9 Issue 3, March 2020}




\section{International Journal of Science and Research (IJSR) \\ ISSN: 2319-7064}

ResearchGate Impact Factor (2018): 0.28 | SJIF (2019): 7.583

epithelialization (14). Other works reports that the use of PRP in combination with insulin showed enhanced ASC differentiation potential (15). In addition, Chung team (12) demonstrated that PEGylated fibrin gel was a good ASCcarrying scaffold for encouraging local angiogenesis. This work was re-established by (13) that incorporation of PRP into gelatin-nanohydroxyapatite fibrous scaffold yielded stronger osteogenic and endothelial differentiation. Bayati team (14) demonstrated recently that when adipose-derived Stromal vascular fraction cells were seeded on electrospun polycaprolactone fibers luxuriant differentiation of keratinocyte was observed in vitro and wound healing in vivo. Human esophageal regeneration where sourced ECM was prepared along with autologous PRP adhesive gel was also reported (16). Also, extended application of PRP into cosmetic surgery has been documented to be effective in arrest capillary bleeding in the surgical flaps of patients submit to various surgery procedures like face lift, breast augmentation or neck lifts (17).

Given the proliferative and multilineage differentiation potential of stromal vascular fraction, they have been deployed in many treatment methods in clinical cell therapy as follows viz:

- The fibrotic and trophic features of ASC are found suitable for smooth and skeletal muscle regenerative challenges, osteoarthritis and degenerative disc diseases (18).

- The possibilities of these cells to enhance cancerous cell progression shift their application in cosmetic reconstructive surgery to a subject of future findings (19, 20, and 21). In particular, autologous ASCs/SVF has been found to be effective in the regeneration of widespread traumatic calvarial bone defects (22), cranio-maxillofacial hard-tissue defects (23).

- SVF has also been deployed in the repair tracheomediastinal fistulas and chronic ulcer caused by cancer ablation (24) as well as treatment of intractable ulcers,

- Treatment of inflammatory disease (25), liver failure (immunodulation and antiapoptotic mechanism (26)), complication related to diabetes mellitus such as nephropathy (27), retinopathy (28) and foot ulcer have been reversed courtesy of cytokines, and chemokines secretion, angiogenesis and vascularization by SVF cells (29), multiple sclerosis diseases, orthopaedic disorders (immunosuppressive, osteoinductive and antiinflammatory features $(28,31,30)$, hair loss, fertility problems (32), and salivary gland damage have been demonstrated in in vivo and clinical study (33).

Tobita and Jeong works $(34,35)$ detailed benefit of combined use of SVF and PRP in skin regeneration. Grafted adipose tissue has been reported to survive greatly when SVF and PRP are combined. Plastic and reconstructive surgery of lower limbs in post-traumatic lower extremity ulcers according to (29 and 30.) have benefited from a mix of PRP combination with SVF. The efficacy claim of PRP and SVF/ASCs combination in fat grafting was reestablished by works of $35,36,37,38,39$ and 40 in the treatment of facial rejuvenation, scars on the face, soft tissue defects and breast reconstruction. Also, the intra-articular injections of autologous ASCs combined with PRP were reported to be effective in cartilage regeneration and silencing of clinical symptoms in unresolved symptomatic knee osteoarthritis. Furthermore, (Limoli PG et al.) showcased an improved retinal functionality in Age-related macular degeneration patients with a combined SVF and PRP treatment.

\section{Conclusion}

This review is important because we now the metabolic features of fat cells are not unrelated to their anatomic origin which invariably determines their gene expression profile that might influence the long-term characteristics of the fat graft (Gentile P, et al. and Aksu et al.) established the relationship between gender, adipose tissue depth and their osteogenic differentiation with male fat tissue of superficial origin tissue differentiating faster while in female tissue origin depth had no effect. This review maintains that the SVF of adipose origin preserves their ability to differentiate toward adipogenic, osteogenic and chondrogenic lineages with no significant differences regarding gene specific expression. However, for practicality, the GIDSVF1 is the most fitting device in an operating room for been closed system that remarkably limit the microbial contamination allowing surgical unit and GMP-laboratories to preserve the safety of the patient and couple with the ready-to-use Collagenase kit as the edge corroborated by the number of TNC and CFU harvested in comparison to other approach. The review further raised the question for most favourable concentration of platelets, leukocytes and other plasma components which researchers have to clarify keeping in mind that PRP effect is not only based on thrombocytes concentration. The review of recent advances in PRP is constrained by lack of data on its long time application, lack of standardization for PRP preparation protocol which customarily results into qualitative differences among reports and questions homogeneity of products. This review advances the field of stem cell therapy by presenting with an indicator of adipogenic potential and commitment 'peroxisome proliferator-activated receptor- $\gamma$ ' (PPAR- $\gamma$ ) is more expressed in the adipose tissue originating from the arm. On top of that, we have evidence that the ability of adipose precursors to grow and differentiate varies among different fat depots and changes with age with an increased PPAR- -2 - 2 expression in younger subjects in all depots while the older patients only could match at the arm and thigh depots. We discovered the abdominal subcutaneous adipose tissue as the least susceptible to apoptotic stimuli (Schipper BM, Marra KG, Zhang W et al). Stromal vascular fractions of flank and thigh origin are optimal in osteogenetic capabilities as against arm and abdomen sourced adipose tissues. Though, the former has poor adipogenic differentiation potential due to low expression of $\mathrm{HOX}$ genes.

\section{References}

[1] Voja Pavlovic*, Milan Ciric, Vladimir Jovanovic, Predrag Stojanovic Platelet Rich Plasma: a short overview of certain bioactive components. Open Med. 2016; 11: 242-247

[2] Franchini $\mathbf{M}^{1,2}$, Cruciani $\mathrm{M}^{1,3}$, Mengoli $\mathrm{C}^{1}$, Marano $\mathrm{G}^{1}$, Pupella $\mathrm{S}^{1}$, Veropalumbo $\mathrm{E}^{1}$, Masiello $\mathrm{F}^{1}$, Pati

\section{Volume 9 Issue 3, March 2020}




\section{International Journal of Science and Research (IJSR) \\ ISSN: 2319-7064}

ResearchGate Impact Factor (2018): 0.28 | SJIF (2019): 7.583

$\mathrm{I}^{1}$, Vaglio $\mathrm{S}^{1}$, Liumbruno $\mathrm{GM}^{1}$. Efficacy of platelet-rich plasma as conservative treatment in orthopaedics: a systematic review and meta-analysis. Blood Transfus. 2018 Nov; 16(6):502-513

[3] Pablo Bora and Anish S. Majumdar, Adipose tissuederived stromal vascular fraction in regenerative medicine: a brief review on biology and translation. Stem Cell Res Ther, 2017; 8: 145.

[4] Pietro Gentile, A,B* Maria Giovanna Scioli,C* Alessandra Bielli,C Augusto Orlandi,C Valerio Cervelli, Concise Review: The Use of Adipose-Derived Stromal Vascular Fraction Cells and Platelet Rich Plasma in Regenerative Plastic Surgery. STEM CELLS 2017; 35:117-134

[5] Zuk PA, Zhu M, Mizuno $\mathrm{H}$ et al. Multilineage cells from human adipose tissue: Implications for cell-based therapies. Tissue Eng 2001; 7:211-228.

[6] Fanny Rodriguez, 1 Cyrille Debard, 1 Jacqueline Adobati, 5 Fabien Boucher, 6 Frédéric Mallein-Gerin, 3 Céline Auxenfans, 1 Odile Damour, 1 and Ali Mojallal 2,6, Evaluation of Three Devices for the Isolation of the Stromal Vascular Fraction from Adipose Tissue and for ASC Culture: A Comparative Study, Stem Cells Int. 2017;2017:9289213.

[7] Massimo Franchini, ${ }^{1,2}$ Mario Cruciani, ${ }^{1,3}$ Carlo Mengoli, ${ }^{1}$ Giuseppe Marano, ${ }^{1}$ Simonetta Pupella, ${ }^{1}$ Eva Veropalumbo, ${ }^{1}$ Francesca Masiello, ${ }^{1}$ Ilaria Pati, ${ }^{1}$ Stefania Vaglio, ${ }^{1}$ and Giancarlo M. Liumbruno1. Efficacy of platelet-rich plasma as conservative treatment in orthopaedics: a systematic review and meta-analysis. Blood Transfus. 2018 Nov; 16(6): 502513.

[8] Da Costa RM, Ribeiro Jesus FM, Aniceto C et al. Randomized, double-blind, placebo-controlled, doseranging study of granulocyte-macrophage colony stimulating factor in patients with chronic venous leg ulcers. Wound Repair Regen 1999; 7:17-25.

[9] Morimoto N, Yoshimura K, Niimi M et al. An exploratory clinical trial for combination wound therapy with a novel medical matrix and fibroblast growth factor in patients with chronic skin ulcers: A study protocol. Am J Transl Res 2012; 4:52-59.

[10] Kazakos K, Lyras DN, Verettas D et al. The use of autologous PRP gel as an aid in the management of acute trauma wounds. Injury 2009; 40:801-805.

[11] Yun Qian, ${ }^{1,2, \dagger}$ Qixin Han, ${ }^{3, \dagger}$ Wei Chen,,${ }^{1,2, \dagger}$ Jialin Song, ${ }^{1,2}$ Xiaotian Zhao, ${ }^{4}$ Yuanming Ouyang, ${ }^{1,2, *}$ Weien Yuan,, and Cunyi Fan ${ }^{1, *}$ Platelet-Rich Plasma Derived Growth Factors Contribute to Stem Cell Differentiation in Musculoskeletal Regeneration. Front Chem. 2017; 5: 89

[12] Chung E, Rytlewski JA, Merchant AG et al. Fibrinbased 3D matrices induce angiogenic behaviour of adipose-derived stem cells. Acta Biomater 2015; 17:7888.

[13] J A, Kuttappan S, Keyan KS et al. Evaluation of osteoinductive and endothelial differentiation potential of Platelet-Rich Plasma incorporated GelatinNanohydroxyapatite Fibrous Matrix. J Biomed Mater Res B Appl Biomater 2016;104: 771-781.

[14] Bayati V, Abbaspour MR, Dehbashi FN et al. A dermal equivalent developed from adipose-derived stem cells and electrospun polycaprolactone matrix: An in vitro and in vivo study. Anat Sci Int 2016 [Epub ahead of print].

[15] Valerio Cervelli, ${ }^{\mathrm{a},}$ "* Maria G. Scioli, ${ }^{\mathrm{b}, *}$ Pietro Gentile, ${ }^{\mathrm{a}}$ Elena Doldo, ${ }^{\mathrm{b}}$ Elena Bonanno, ${ }^{\mathrm{b}}$ Luigi G. Spagnoli, ${ }^{b}$ and Augusto Orlandi ${ }^{\mathrm{b}}$. Platelet-Rich Plasma Greatly Potentiates Insulin-Induced Adipogenic Differentiation of Human Adipose-Derived Stem Cells Through a Serine/Threonine Kinase Akt-Dependent Mechanism and Promotes Clinical Fat Graft Maintenance. Stem Cells Transl Med. 2012; 1(3): 206220.

[16]Dua KS, Hogan WJ, Aadam AA et al. Invivo oesophageal regeneration in a human being by use of a non-biological scaffold and extracellular matrix. Lancet 2016; 388: 55-61.

[17] Amorim NF et al. Expanded stem cells, stromalvascular fraction, and platelet-rich plasma enriched fat: Comparing results of different facial rejuvenation approaches in a clinical trial. Aesthet Surg J 2016; 36:261-270.

[18] Ramil Z. Salikhov 1,2, Ruslan F. Masgutov 1,3*, Mikhail A. Chekunov 1, Leysan G. Tazetdinova3, Galina Masgutova3, Oleg V. Teplov 1, Damir Galimov 1,3, Yuri Plakseichuk1, Ramil Yagudin1, Igor O. Pankov 2 and Albert Rizvanov 1,3 The Stromal Vascular Fraction From Fat Tissue in the Treatment of Osteochondral Knee Defect: Case Report

[19] Man D, Plosker H, Winland-Brown JE. The use of autologous platelet-rich plasma (platelet gel) and autologous platelet-poor plasma (fibrin glue) in cosmetic surgery. Plast Reconstr Surg 2001; 107:229237.

[20] Gentile P, Orlandi A, Scioli MG et al. A comparative translational study: The combined use of enhanced stromal vascular fraction and platelet-rich plasma improves fat grafting maintenance in breast reconstruction. Stem Cells Transl Med 2012; 1:341351.

[21] Gentile P, De Angelis B, Pasin M et al. Adipose-derived stromal vascular fraction cells and platelet-rich plasma: Basic and clinical evaluation for cell-based therapies in patients with scars on the face. J Craniofac Surg 2014; 25:267-272

[22] Lendeckel S, Jo €dicke A et al. Autologous stem cells (adipose) and fibrin glue used to treat widespread traumatic calvarial defects: Case report. J Craniomaxillofac Surg 2004; 32:370-373.

[23] Sandor GK, Numminen J, Wolff J et al. Adipose stem cells used to reconstruct 13 cases with craniomaxillofacial hard-tissue defects. Stem Cells Transl Med 2014; 3:530-540.

[24] Alvarez PD, Garc_1a-Arranz M, Georgiev-Hristov T et al. A new bronchoscopic treatment of tracheomediastinal fistula using autologous adiposederived stem cells. Thorax 2008; 63:374-376.

[25]Ming Zhu, ${ }^{1, *}$ Jian Xue, ${ }^{1, *}$ Shiliang $\mathrm{Lu},{ }^{1} \mathrm{Yi}$ Yuan, ${ }^{2}$ Yunjun Liao, ${ }^{2}$ Jingjing Qiu, ${ }^{1}$ Cheng Liu, ${ }^{1}$ and Qingting Liao ${ }^{1}$. Anti-inflammatory effect of Stromal vascular fraction cells in fat transplantation Exp Ther Med. 2019 Feb; 17(2): 1435-1439.

[26] Joaquin Cagliani, MD, ${ }^{1,2}$ Daniel Grande, $\mathrm{PhD},{ }^{3}$ Ernesto P Molmenti, MD, PhD MBA, ${ }^{4}$ Edmund J. Miller, $\mathrm{PhD},{ }^{1}$ and Horacio L.R. Rilo, $\mathrm{MD}^{5}$, Immunomodulation 


\section{International Journal of Science and Research (IJSR) \\ ISSN: 2319-7064}

ResearchGate Impact Factor (2018): 0.28 | SJIF (2019): 7.583

by Mesenchymal Stromal Cells and Their Clinical Applications. J Stem Cell Regen Biol. 2017; 3(2): 10.15436/2471-0598.17.022.

[27] Sandra Villanueva, ${ }^{1}$ Fernando González, ${ }^{2}$ Eduardo Lorca, ${ }^{2}$ Andrés Tapia, ${ }^{3} \mathrm{G}$ Valentina López, ${ }^{4}$ Rocío Strodthoff, ${ }^{1}$ Francisca Fajre, ${ }^{1}$ Juan E. Carreño, ${ }^{1}$ Ricardo Valjalo, ${ }^{2}$ César Vergara, ${ }^{1}$ Manuel Lecanda, ${ }^{1}$ Jorge Bartolucci, ${ }^{4}$ Fernando E. Figueroa, $\otimes^{3,5,6, *}$ and Maroun Khoury $\otimes^{3,4,5, *}$. Adipose tissue-derived mesenchymal stromal cells for treating chronic kidney disease: A pilot study assessing safety and clinical feasibility. Kidney Res Clin Pract. 2019 Jun; 38(2): 176-185.

[28] Reza Tabatabaei Qomi, Mohsen Sheykhhasan Adiposederived stromal cell in regenerative medicine: A review World J Stem Cells 2017 August 26; 9(8): 107-117

[29] Cervelli V, Gentile P, De Angelis B et al. Application of enhanced stromal vascular fraction and fat grafting mixed with PRP in post traumatic lower extremity ulcers. Stem Cell Res 2011; 6:103-111

[30] Cervelli V, De Angelis B, Lucarini L et al. Tissue regeneration in loss of substance on the lower limbs through use of plateletrich plasma, stem cells from adipose tissue, and hyaluronic acid. Adv Skin Wound Care 2001; 23:262-272

[31] Limoli PG, Vingolo EM, Morales MU et al. Preliminary study on electrophysiological J A, Kuttappan S, Keyan KS et al. Evaluation of osteoinductive and endothelial differentiation potential of Platelet-Rich Plasma incorporated Gelatin-Nanohydroxyapatite Fibrous Matrix. J Biomed Mater Res B Appl Biomater 2016; 104:771-781.Aksu AE, Rubin JP, Dudas JR et al. Role of gender and anatomical region on induction of osteogenic differentiation of human adipose-derived stem cells. Ann Plast Surg 2008; 60:306-322.

[32] Garber MG and Carlos NDIntracavernous Administration of Adipose Stem Cells: A New Technique of Treating Erectile Dysfunction in Diabetic Patient, Preliminary Report of 6 Cases. MOJ Cell Sci (2015): $\quad$ Rep 2(1): $00018 . \quad$ DOI: 10.15406/mojcsr.2015.02.00018

[33] Kristin Comella ${ }^{1}$ and Walter Bell ${ }^{2}$. First-in-man intraglandular implantation of stromal vascular fraction and adipose-derived stem cells plus platelet-rich plasma in irradiation-induced gland damage: a case study. Int Med Case Rep J. 2017; 10: 295-299.

[34] Tobita M, Tajima S, Mizuno H. Adipose tissue-derived mesenchymal stem cells and platelet-rich plasma: Stem cell transplantation methods that enhance stemness. Stem Cell Res Ther 2015; 6:215.

[35] Jeong JH. Adipose stem cells and skin repair. Curr Stem Cell Res Ther 2010; 5:137-140.

[36] Rigotti G, Charles-de-S_a L, Gontijo-de-Amorim NF et al. Expanded stem cells, stromal-vascular fraction, and platelet-rich plasma enriched fat: Comparing results of different facial rejuvenation approaches in a clinical trial. Aesthet Surg J 2016; 36:261-270.

[37] Gentile P, Orlandi A, Scioli MG et al. Concise review: Adipose-derived stromal vascular fraction cells and platelet-rich plasma: Basic and clinical implications for tissue engineering therapies in regenerative surgery. Stem Cells Transl Med 2012; 1:230-236

[38]Han $\mathrm{S}^{1}$, Sun $\mathrm{HM}^{2}$, Hwang $\mathrm{KC}^{2}$, Kim $\mathrm{SW}^{2}$. AdiposeDerived Stromal Vascular Fraction Cells: Update on
Clinical Utility and Efficacy. Crit. Rev. Eukaryot Gene Expr. 2015; 25(2):145-52.

[39] Tejaswi Iyyanki, MS; Justin Hubenak, BS; Jun Liu, PhD; Edward I. Chang, MD; Elisabeth K. Beahm, MD; and Qixu Zhang, MD, PhD, Harvesting Technique Affects Adipose-Derived Stem Cell Yield: Aesthetic Surgery Journal 2015, Vol 35(4) 467-476

[40] Schipper BM, Marra KG, Zhang W et al. Regional anatomic and age effects on cell function of human adipose-derived stem cells. Ann Plast Surg 2008; 60:538- 544 .

[41] Limoli $\mathrm{PG}^{1}$, Vingolo EM, Morales MU, Nebbioso M, Limoli C. Preliminary study on electrophysiological changes after cellular autograft in age-related macular degeneration. Medicine (Baltimore). 2014 Dec; 93(29):e355. doi: 10.1097/MD.0000000000000355.

\section{Author Profile}

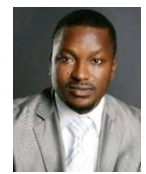

Fasasi Olaleke Bashir, BMLS, MSc. and $\mathrm{PhD}$, a Director of Embryology Services in Nigeria is a graduate of Ambrose Alli University, University of Leeds, Britain and Panama College of Cell Science, Panama. His specialization in micromanipulation make him a sought after instructor in the Assisted Reproduction Technology (A.R.T.) industry. $\mathrm{He}$ is a guest lecturer at various symposium, colloquium and Biomedical Science Conferences held in Nigeria. Olaleke assisted conception hands-on prowess is in excess of fifteen years. He is a recipient of the STAR performer award as an Embryologist in Nigeria in the year 2007. 